\title{
Growth, production and yield of common bean under water replacement levels
}

\author{
Ivomberg D. Magalhães ${ }^{1}$, Guilherme B. Lyra ${ }^{1}$, José L. de Souza ${ }^{1}$, Gustavo B. Lyra ${ }^{2}$, \\ Rener L. de S. Ferraz ${ }^{3} \&$ Constantino A. Cavalcante Júnior ${ }^{1}$
}

\begin{abstract}
${ }^{1}$ Universidade Federal de Alagoas/Centro de Ciências Agrárias. Rio largo, AL, Brasil. E-mail: ivomberg31@hotmail.com - ORCID: 00000003-2959-2698; gbastoslyra@yahoo.com.br - ORCID: 0000-0002-6186-2048; leonaldojs@yahoo.com.br - ORCID: 0000-0002-5399-856X; constantinocavalcante@hotmail.com - ORCID: 0000-0002-3911-2961

${ }^{2}$ Universidade Federal Rural do Rio de Janeiro/Instituto de Florestas. Seropedica, RJ, Brasil. E-mail: gblyra@gmail.com - ORCID: 0000-0002-9882-7000

${ }^{3}$ Universidade Estadual da Paraíba/Centro de Ciências Agrárias e Ambientais. Lagoa Seca, PB, Brasil. E-mail: ferragroestat@gmail.com (Corresponding author) - ORCID: 0000-0002-9423-4435
\end{abstract}

\begin{abstract}
The bean is a world-class crop and requires adequate water management for higher yield. The objective of this study was to evaluate the growth and the production and to fit multiple regression models to estimate the production components, total biomass accumulation and grain yield of 'Rosinha' bean under levels of replacement of evapotranspired water. The experimental design was randomized blocks with four repetitions. Treatments consisted of fractions of crop evapotranspiration (25, 50, 75, 100, 125 and 150\% ETc). Growth variables (plant height, number of leaves, leaf area per plant, leaf area index, stem dry mass and leaf dry mass) and production components (number of pods per plant, pod length, pod diameter, pod dry mass, total biomass, pod mass per plant, grain yield) were evaluated. Measurements of growth variables carried out at 35 days after sowing were used to fit multiple regression models to estimate dry pod mass, total biomass accumulation and grain yield of common bean. Higher growth and yield of common bean, 'Rosinha', are obtained with irrigation depth corresponding to $100 \%$ of the evapotranspired water.
\end{abstract}

Key words: Phaseolus vulgaris, irrigation, multivariate

\section{Crescimento, produção e rendimento de feijoeiro sob níveis de reposição de água}

RESUMO: O feijão é uma cultura de importância mundial e requer manejo adequado de água para maior produtividade. Objetivou-se avaliar o crescimento e a produção e ajustar modelos de regressão múltipla para estimativa de componentes de produção, acúmulo de biomassa total e rendimento de grãos do feijoeiro variedade Rosinha sob níveis de reposição da água evapotranspirada. O delineamento utilizado foi em blocos ao acaso com quatro repetições. Os tratamentos consistiram de frações da evapotranspiração da cultura (25, $50,75,100,125$ e 150\% ETc). Foram avaliadas variáveis de crescimento (altura de plantas, número de folhas, área foliar por planta, índice de área foliar, massa seca do caule e das folhas) e componentes de produção (número de vagens por planta, comprimento de vagens, diâmetro de vagem, massa seca de vagem, biomassa total, massa de vagem por planta, rendimento de grãos). As medidas de crescimento realizadas aos 35 dias após a semeadura foram utilizadas para ajustar modelos de regressão múltipla para estimativa de massa seca de vagem, acúmulo de biomassa total e rendimento de grãos do feijoeiro. Maior crescimento e produção do feijoeiro, 'Rosinha', são obtidos com a lâmina de irrigação de 100\% da água evapotranspirada.

Palavras-chave: Phaseolus vulgaris, irrigação, multivariada 


\section{INTRODUCTION}

Cultivation of common beans (Phaseolus vulgaris L.) in countries of tropical and subtropical climate are important sources of food, due to the low cost for the consumer and because it is nutritionally balanced, as well as the main source of protein for low-income populations (Souza et al., 2016; Padilla-Chacón et al., 2017).

Common bean yield in Brazil is low (827 $\mathrm{kg} \mathrm{ha}^{-1}$ ), mainly due to the low technological level used in its cultivation and to the irregularities of rainfall. In Brazil, 'Carioca' bean is the most produced, with black bean in second place, and 'Mulatinho' bean in third place, followed by the 'Rosinha' group (CONAB, 2017). Crede seeds of common bean, belonging to the 'Rosinha' group, have good yield and low incidence of pests and diseases, presenting themselves as a good option for cultivation in the Brazilian semiarid region (Michels et al., 2014).

The Northeast region of Brazil is one of the main producers of common bean (Brito et al., 2016). In the year 2016, the state of Alagoas, Brazil, produced 15.1 thousand tons (mean yield of $500 \mathrm{~kg} \mathrm{ha}^{-1}$ ), and this value combined with the productions of Sergipe and Bahia states represents $22 \%$ of northeastern production (CONAB, 2016).

Irrigation is indicated as a potential technology with capacity to increase common bean production, since there are reports of yields around $3,500 \mathrm{~kg} \mathrm{ha}^{-1}$ in irrigated crops in several regions of Brazil (CONAB, 2017). Poorly planned irrigation in agriculture is a cause for concern, mainly due to the large amount of water used in this sector; however, when rationally conducted, it is an important strategy for optimizing agricultural production, promoting sustainable development, generating jobs and income (Liang et al., 2016).

The reduction of water availability in soil causes a decrease in common bean yield, precisely because it limits its growth and development (Abd El-Wahed et al., 2017). Thus, research is decisive for promoting increase of yield and competitive economic returns.

This study aimed to evaluate the growth and production and adjust multiple regression models to estimate the production components, total biomass accumulation and grain yield of common bean, 'Rosinha' variety, under levels of replacement of the evapotranspired water.

\section{Material and Methods}

The experiment was conducted in the city of Rio Largo, AL, Brazil (9 $28^{\prime} 2^{\prime \prime}$ S; $35^{\circ} 49^{\prime} 43^{\prime \prime} \mathrm{W}$; and altitude of $127 \mathrm{~m}$ ). The climate of the region, according to Thornthwaite climate classification, is humid and megathermal, with moderate water deficit in the summer and excess in the winter; the average annual temperature is $25.4^{\circ} \mathrm{C}$ and average annual precipitation is around $1,800 \mathrm{~mm}$, of which $70 \%$ is concentrated in the months from April to August (Souza et al., 2005; Ferreira Junior et al., 2014). Meteorological data were collected at an automatic weather station (CR3000, Campbell Scientific) located $30 \mathrm{~m}$ away from the experimental area. At $10 \mathrm{~min}$ intervals, the following meteorological elements were measured: temperature $\left(\mathrm{T},{ }^{\circ} \mathrm{C}\right)$ and air relative humidity $(\mathrm{RH}, \%)$, wind velocity at $2 \mathrm{~m}$ height $\left(\mathrm{U}^{2}, \mathrm{~m} \mathrm{~s}^{-1}\right)$ and precipitation $(\mathrm{P}, \mathrm{mm})$.

The local soil is classified as Oxisol with medium/clayey texture, with slope less than $2 \%$. Basal fertilization was applied according to soil chemical analysis (Table 1), using $45 \mathrm{~kg}$ of urea, $111 \mathrm{~kg}$ of single superphosphate and $78 \mathrm{~kg}$ of potassium chloride per hectare. At 20 days after sowing (DAS), topdressing fertilization was applied, using $89 \mathrm{~kg} \mathrm{ha}^{-1}$ of urea. Spontaneous plants and pests were controlled by manual weeding and synthetic insecticides, respectively.

The seeds used were crede seeds of the 'Rosinha' variety, which has an average 100-seed weight of $21.3 \mathrm{~g}$, upright and indeterminate growth habit, flowering at 34 and maturity at 78 days after emergence, grain yield of $174 \mathrm{~g} \mathrm{~m}^{-2}$ and harvest index of $592 \mathrm{mg} \mathrm{g}^{-1}$ (Araújo \& Teixeira, 2012). Sowing was performed manually, distributing three seeds per hole at spacing of $0.50 \mathrm{~m}$ between rows and density of 13 to 15 plants per linear meter, totaling a final stand of 250,000 plants ha ${ }^{-1}$. At 15 DAS, thinning was performed, leaving one plant per hole.

The study was carried out during the dry season (less rainy) in the period from November to February (2015/2016). The design used was randomized blocks with four repetitions. Each experimental unit was 8 by $10 \mathrm{~m}$. Treatments consisted of six irrigation depths $[25,50,75,100,125$ and $150 \%$ of crop evapotranspiration (ETc)]. All treatments received the same level of water replacement $(100 \% \mathrm{ETc})$ in the initial period (15 DAS).

The total water depths applied (irrigation + precipitation) along the crop cycle for the percentages of 25, 50, 75, 100, 125 and $150 \%$ ETc were $462.5,504.9,543.6,577.9,614.5$ and 866.85 $\mathrm{mm}$, respectively.

Crop coefficients $\mathrm{kc}$ of 1.1 and 1.2 were adopted for the vegetative and reproductive stages, respectively. These kc values are recommended by the FAO- 56 bulletin for the intermediate stage and were adjusted to the edaphoclimatic conditions and the characteristics of the crop during the experimental period. ETc values were calculated using Eq. 1.

$$
\mathrm{ETc}=\mathrm{ETo} \mathrm{kc}
$$

where:

ETc - crop evapotranspiration, $\mathrm{mm} \mathrm{d}^{-1}$;

$\mathrm{ET}_{\mathrm{o}}$ - reference evapotranspiration estimated by the Penman-Monteith-FAO method (Allen et al., 1998), $\mathrm{mm} \mathrm{d}^{-1}$; and,

kc - crop coefficient.

Irrigation was applied by emitters at spacing of $2 \mathrm{~m}$ between rows and $2.5 \mathrm{~m}$ between micro-sprinklers, at service pressure

Table 1. Soil chemical attributes of the experimental area

\begin{tabular}{|c|c|c|c|c|c|c|c|c|c|c|c|}
\hline \multirow{2}{*}{$\begin{array}{l}\text { Layer } \\
\text { (cm) }\end{array}$} & \multirow{2}{*}{ pH } & $1 \mathbf{P}$ & $\mathrm{Ca}$ & $\mathrm{Mg}$ & $K$ & SB & $\mathrm{Al}$ & $\mathrm{H}+\mathrm{Al}$ & $T$ & $m$ & \multirow{3}{*}{$\begin{array}{c} \\
(\%) \\
442\end{array}$} \\
\hline & & & $\mathrm{ng} \mathrm{dm}$ & & \multicolumn{6}{|c|}{$\left(\mathrm{cmol}_{\mathrm{c}} \mathrm{dm}^{-3}\right)$} & \\
\hline $0-20$ & 5.8 & 15.2 & 2.7 & 1.3 & 1.15 & 4.21 & 0.08 & 5.4 & 9.61 & 1.5 & \\
\hline
\end{tabular}

pH - Hydrogen potential; P - Phosphorus, Mehlich'; Ca - Calcium; Mg - Magnesium; K - Potassium; SB - Sum of bases; Al - Aluminum; H+Al - Hydrogen plus aluminum; - Cation exchange capacity; $\mathrm{m}$ - Aluminum saturation; $\mathrm{v}$ - Base saturation 
of $137.2 \mathrm{kPa}$, with average flow rate of $50 \mathrm{~L} \mathrm{~h}^{-1}$ per emitter, application rate of $8.9 \mathrm{~mm} \mathrm{~h}^{-1}$ and water application uniformity of $98 \%$. Lima et al. (2011) report that micro-sprinkler irrigation is more suitable for the bean crop, because it reduces losses caused by the Bean Golden Mosaic Virus. Soil water content in the root zone $(\mathrm{W}, \mathrm{mm})$ was obtained by measurements of volumetric soil water content every $30 \mathrm{~min}$ by sensors using the time-domain reflectometry (TDR) technique (CS616, Campbell Scientific), connected to a CR1000 data acquisition system. The probes were positioned vertically in the soil, $0.15 \mathrm{~m}$ away from the plants and inside the central rows, in at 0-0.30 $\mathrm{m}$ depth, according to the methodology recommended by Rocha et al. (2014).

Growth analysis was performed at 35 DAS in five plants of each plot, between the pre-flowering and pod formation, at the R5 stage (Fernandez et al., 1982). The following growth variables were evaluated: plant height $(\mathrm{PH}, \mathrm{cm})$; number of leaves $\left(\mathrm{NL}\right.$, plant $\left.{ }^{-1}\right)$; leaf area per plant $\left(\mathrm{LAP}, \mathrm{m}^{2}\right)$; leaf area index (LAI); stem dry mass (SDM, g); and leaf dry mass (LDM, g). In relation to the biometric parameters, trifoliate leaves were detached from the petioles to determine the leaf area using a planimeter (Li-Cor, Li-3100 model), with the results expressed in $\mathrm{m}^{2}$. LAI was determined by LAP/AOP ratio, in which AOP is the area occupied by the plant $\left(\mathrm{m}^{2}\right)$ (Floss, 2004).

At the end of the experiment (78 DAS), the following production components were evaluated: number of pods per plant (NP, units plant ${ }^{-1}$ ), pod length $(\mathrm{PL}, \mathrm{cm})$, pod diameter (PD, cm), pod dry mass (PDM, g), total biomass (TBM, g), pod mass per plant (PMP, g), grain yield (GY, $\mathrm{kg} \mathrm{ha}^{-1}$ ).

For dry mass determination, collected plants were subjected to drying in a forced air circulation oven at $65^{\circ} \mathrm{C}$ until constant weight. Then, they were weighed on scales with precision of $0.001 \mathrm{~g}$ to obtain the dry mass, expressed in g. For grain yield (GY) determination, the four central rows with length of $5 \mathrm{~m}$ were harvested, totaling $10 \mathrm{~m}^{2}$ for each plot. The GY was calculated by correcting the moisture to $13 \%$ (wet basis) and determined by the oven method at $105^{\circ} \mathrm{C}$ for $24 \mathrm{~h}$ (Brasil, 1992).

The data were standardized for zero mean $(\mathrm{X}=0)$ and unit variance $\left(\sigma^{2}=1\right)$. The multivariate structure of the results was evaluated using the exploratory principal component analysis (PCA), concentrating the amount of relevant information contained in the original data set in a smaller number of dimensions, resulting from linear combinations of the original variables generated from the highest eigenvalues in the covariance matrix (Hair et al., 2009).

From the reduction of the dimensions, the original data of the variables of each principal component (PC) were subjected to multivariate analysis of variance (MANOVA) by the Hotelling Test (Hotelling, 1947) at $p \leq 0.05$ as a function of the irrigation depths based on ETc. The variables of the PC associated with the production components NP, PDM, PMP, TBM and GY were subjected to multiple linear regression analysis, considering each production component as a dependent variable and the other variables contained in the same PC, plus the irrigation depths based on ETc, as independent variables, in order to adjust a predictive model for the production components. The multiple linear regression model (Eq. 2) with $\mathrm{k}$ independent variables was used:

$$
\mathrm{PRC}=\alpha+\sum_{\mathrm{i}=1}^{\mathrm{k}} \beta_{\mathrm{i}} \mathrm{X}_{\mathrm{ij}}+\varepsilon_{\mathrm{j}}
$$

where:

PRC - each production component;

a - linear coefficient;

$\beta \mathrm{i}$ - regression coefficient of the independent variables;

$\mathrm{X}_{\mathrm{ij}} \quad$ - independent variables $\mathrm{X}_{\mathrm{i}}$ in the observation $\mathrm{j}$;

$\varepsilon_{j} \quad$ - error associated with PRC in the observation $j$ (Cargnelutti Filho et al., 2004); and,

k - number of independent variables.

\section{Results AND Discussion}

During the experiment (November 17, 2015 to February 01, 2016), a precipitation of $291.60 \mathrm{~mm}$ with irregular distribution was recorded, denoting the need for irrigation to meet the common bean water demand. There was intermittent precipitation with the concentration of $98 \%$ of the rains from the second half of December when the crop was in the early reproductive stage. The effect of irrigation depths based on ETc was evident during the stages R5 to R7 (Fernandez et al., 1982). In these periods, plants showed maximum development of the vegetative canopy and, consequently, a large transpiring surface. As the above-mentioned stages coincided with the second half of December, a period of higher occurrence of precipitation, there were low values of evapotranspiration (Figure 1).

The multidimensional space of the original variables was reduced to two dimensions, represented by the first two principal components ( $\mathrm{PC}_{1}$ and $\mathrm{PC}_{2}$ ) with eigenvalues greater than one $(\lambda>1)$. Together, these PCs explain $90.2 \%$ of the total variance. $\mathrm{PC}_{1}$ explains $69.04 \%$ of the total variance, being formed by the growth and production components, and $\mathrm{PC}_{2}$ represents $21.15 \%$ of the remaining variance, formed by biometric characteristics of pods (Figure 2). The irrigation depths based on ETc had a significant effect $(\mathrm{p} \leq 0.001)$ on the variables of the two PCs (Table 2).

The two-dimensional projections of treatment effects and variables, respectively, in the first and second principal

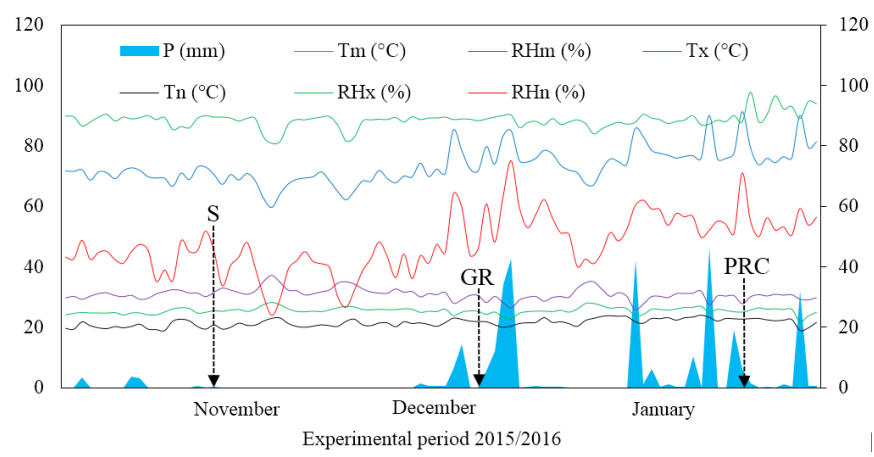

P - Precipitation; Tm - Mean air temperature; Tn - Minimum air temperature; Tx - Maximum air temperature; $\mathrm{RHm}$ - Mean air relative humidity; $\mathrm{RHn}$ - Minimum air relative humidity; RHx - Maximum air relative humidity; S - Sowing; GR - Growth analysis; PRC - Production components analysis

Figure 1. Meteorological variables recorded during the experimental period 
Table 2. Eigenvalues, proportion of the explained variance, probability of significance of the effect of irrigation depths and coefficients of correlation between the principal components and the original variables

\begin{tabular}{|c|c|c|c|c|c|c|c|c|c|c|c|c|c|c|c|c|}
\hline \multirow{2}{*}{ PCs } & \multirow{2}{*}{$\lambda$} & \multirow[b]{2}{*}{$\sigma^{2} \%$} & \multirow[b]{2}{*}{ p } & \multicolumn{13}{|c|}{ Correlation coefficients (r) } \\
\hline & & & & PH & $\overline{N L}$ & LAP & $\overline{\text { LAI }}$ & SDM & LDM & $\overline{N P}$ & $\overline{\mathrm{PL}}$ & PD & PDM & PMP & TBM & GY \\
\hline $\mathrm{PC}_{1}$ & 8.98 & 69.04 & $1 \mathrm{E}-7$ & $-0.96^{a}$ & $-0.96^{a}$ & $-0.92^{\mathrm{a}}$ & $-0.98^{\mathrm{a}}$ & $-0.74^{\mathrm{a}}$ & $-0.71^{\mathrm{a}}$ & $-0.91^{a}$ & -0.50 & 0.06 & $-0.72^{\mathrm{a}}$ & $-0.99^{\mathrm{a}}$ & -0.97 & $-0.87^{a}$ \\
\hline $\mathrm{PC}_{2}$ & 2.75 & 21.15 & $9 \mathrm{E}-4$ & -0.14 & 0.01 & -0.32 & -0.12 & -0.27 & -0.66 & -0.17 & $0.62^{\mathrm{a}}$ & $0.99^{\mathrm{a}}$ & $0.67^{\mathrm{a}}$ & 0.04 & 0.17 & 0.48 \\
\hline
\end{tabular}

PCs - Principal components; $\lambda$ - Eigenvalues; $\sigma^{2} \%$ - Proportion of explained variance; p - Probability for the effect of irrigation depths by the Hotelling test; PH - Plant height; NL Number of leaves; LAP - Leaf area per plant; LAI - Leaf area index; SDM - Stem dry mass; LDM - Leaf dry mass; NP - Number of pods; PL - Pod length; PD - Pod diameter; PDM - Pod dry mass; PMP - Pod mass per plant; TBM - Total biomass; GY - Grain yield; $r=0.10-0.30$ (weak); $r=0.40-0.60$ (moderate); $r=0.70-1.00$ (strong)

a Variable considered in the principal component

components are presented in Figures $2 \mathrm{~A}$ and $\mathrm{B}$. In $\mathrm{PC}_{1}$, the highest values of plant height $(43 \mathrm{~cm})$, number of leaves $(49)$, leaf area index (6), number of pods (17), pod dry mass (63 g), pod mass per plant $\left(18 \mathrm{~g} \mathrm{plant}^{-1}\right)$ and grain yield $\left(2,230 \mathrm{~kg} \mathrm{ha}^{-1}\right)$ were obtained with the irrigation depth of $125 \%$ ETc, although, except for grain yield, there is no significant difference between the values recorded with the irrigation depths of 100 and $150 \%$ ETc. Increments in PH, NL, LAI, NP, PDM, PMP and GY with $125 \%$ ETc of $9,22,37,44,51,61$ and $39 \%$ compared to the $25 \%$ ETc, and of 5, 17, 28, 35, 38, 43 and 26\%, compared to the $50 \%$ ETc, were observed. For Torres et al. (2013), the water deficit caused by the irrigation depth equivalent to $40 \%$ of the daily crop evapotranspiration reduces the growth and, consequently, the production components and yield of common bean.

Results similar to those obtained in this study with the highest irrigation depths (100 and 125\% ETc) were found by Abd El-Wahed et al. (2017), who studied the effect of irrigation on common bean growth and found 12 pods plant $^{-1}$ and grain yield of 2,258.1 kg ha-1, under $100 \%$ ETc replacement. These researchers confirm that these results are due to the available water in the root zone for these levels, which leads to an increase in the absorption of water and nutrients, consequently increasing the metabolic mechanisms of the plants, increasing the production components. Torres et al. (2013), evaluating the irrigated bean yield and soil covers, observed higher values of yield and numbers of pods and grains per plant when a water depth corresponding to $100 \%$ ETc was applied.

The higher values of stem dry mass ( $72 \mathrm{~g}$ ) and total biomass (175 g) were obtained with the irrigation depth of $100 \%$ ETc,

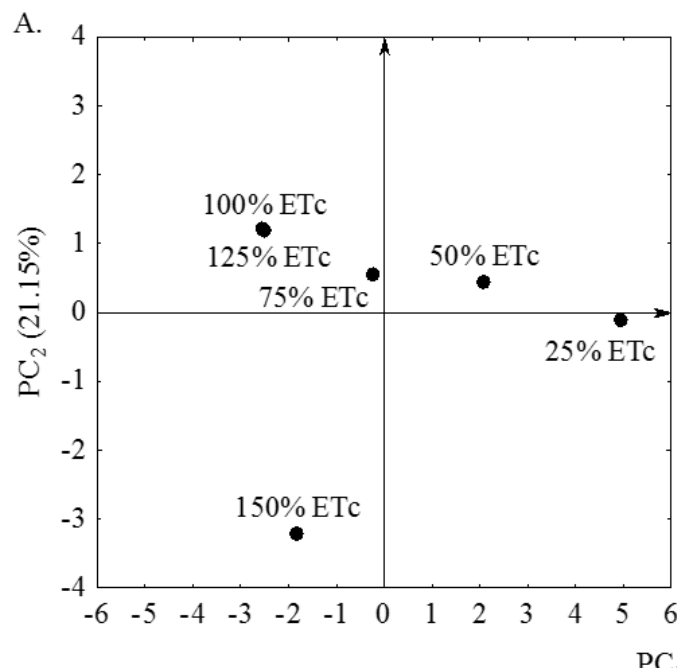

while the irrigation depth of $150 \%$ ETc led to larger leaf area per plant $\left(0.30 \mathrm{~m}^{2}\right.$ plant $\left.\mathrm{t}^{-1}\right)$ and leaf dry mass $(43 \mathrm{~g})$. For these variables, there were, respectively, gains of $29,33,51$ and $21 \%$ in comparison to the irrigation depth of $25 \%$ ETc and increments of $10,19,44$ and $16 \%$ in comparison to the irrigation depth of $50 \%$ ETc.

Higher water supply with the irrigation depth of $100 \%$ ETc may have increased cell turgor and induced increments in leaf mesophyll thickness and leaf area with the increase in the number of chloroplasts (Ferraz et al., 2012b). Thus, it can be inferred that these adaptations promoted regulation in stomatal opening and facilitated the $\mathrm{CO}_{2}$ influx into the substomatal chamber and water vapor efflux to the atmosphere (Ferraz et al., 2012a). These data justify higher values of biomass accumulation than those reported by Goulart et al. (2010), between 12.3 and $17 \mathrm{~g}$, studying six common bean cultivars.

Dutra et al. (2015) state that, in response to water deficit, plants reduce stomatal opening, influencing other variables such as photosynthesis rate and transpiration rate, with negative consequences on growth and development, directly affecting their yield, which justifies the reductions in the growth variables under irrigation depths of 25 and 50\% ETc observed in the present study. Indeed, moderate water deficit caused an increase in the resistance to water vapor due to partial stomatal closure and reduction of stomatal conductance, causing a lower rate of $\mathrm{CO}_{2}$ assimilation and transpiration (Magalhães et al., 2017).

In the second principal component $\left(\mathrm{PC}_{2}\right)$, there was an association of variables related to biometric characteristics

B.

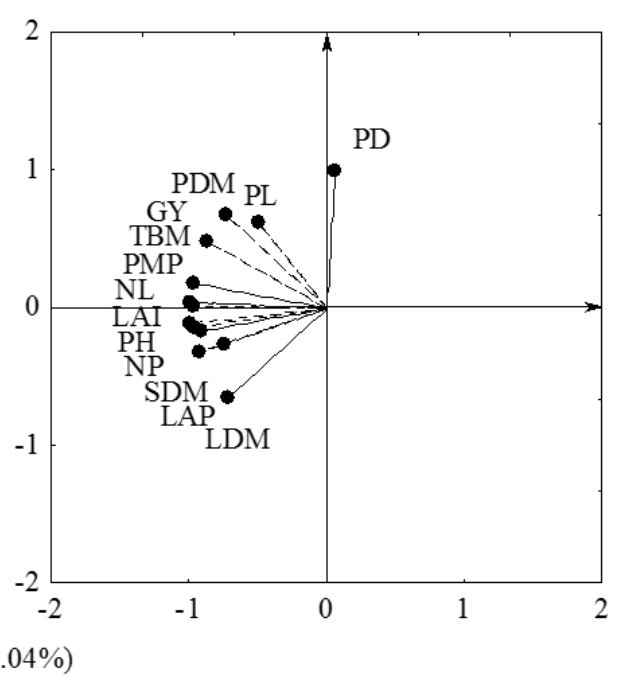

PH - Plant height; NL - Number of leaves; LAP - Leaf area per plant; LAI - Leaf area index; SDM - Stem dry mass; LDM - Leaf dry mass; NP - Number of pods per plant; PL - Pod length per plant; PD - Pod diameter; PDM - Pod dry mass; TBM - Total biomass; PMP - Pod mass per plant; GY - Grain yield

Figure 2. Two-dimensional projection of the crop evapotranspiration - ETc replacement levels (A) and of the variables (B) in the first two principal components $\left(\mathrm{PC}_{1}\right.$ and $\left.\mathrm{PC}_{2}\right)$ 
and biomass accumulation of pods. The longest pod $(9 \mathrm{~cm})$ was obtained with the irrigation depth of $100 \%$ ETc, while the largest pod diameter $(0.97 \mathrm{~cm})$ and pod dry mass $(63 \mathrm{~g})$ were obtained under irrigation depth of $125 \%$ ETc, although for these three variables there was no expressive difference between the irrigation depths of 75, 100 and 125\% ETc, in which the gains were, respectively, of 14,4 and $51 \%$ in comparison to the irrigation depth of $25 \%$ ETc. On the other hand, it was observed that the irrigation depth of $150 \%$ ETc caused expressive reductions in these variables of 13,12 and $46 \%$, respectively, compared to the highest values obtained.

The excess of water caused by the irrigation depth of $160 \%$ of the daily evapotranspiration of the crop caused oxygen deficiency in the soil in certain periods (Torres et al., 2013), which may have reduced the microbial activity in the soil and, consequently, reduced yield. Arf et al. (2004) confirm that the supply of adequate amounts of water is one of the key factors in the production of the bean crop, because both the excess and the deficit hamper crop development and yield, so the demand recommended for the crop should not be exceeded.

Cunha et al. (2013) point out that common bean needs 300 to $600 \mathrm{~mm}$ water depth to obtain high yield. It should be added that the number of pods per plant, pod length, pod diameter and pod dry mass are the principal components that influence yield and significantly respond to irrigation (Ramos Júnior et al., 2005).

Water deficit in the vegetative period directly influences the growth and development of the common bean, causing reduction in its yield (Torres et al., 2013). Ávila et al. (2010), studying common bean cultivation with and without irrigation, state that even with water deficit no longer occurring from early flowering, the yield was lower compared to the irrigated treatment, due to the reduction in the mass of grains and lower number of pods per plant. Thus, the reductions recorded in the present study in pod dry mass, total biomass accumulation and grain yield are associated with the scarcity of water resulting from the replacement lower than the amount required by the crop.

There was a significant multiple regression adjustment ( $\mathrm{p} \leq$ 0.05 ) for the data of pod dry mass, total biomass accumulation and grain yield as a function of irrigation depths and for the growth variables: plant height, number of leaves, leaf area per plant, leaf area index, stem dry mass and leaf dry mass. The measures of quality, precision and proportion of the variability explained by each model are described in Table 3. Based on the multiple coefficient of determination, it is possible to infer that the models can be used with good predictive capacity for estimating pod dry mass, total biomass and grain yield.

The adjusted multiple regression models were used to estimate pod dry mass, total biomass and grain yield from the data observed in each irrigation depth as a function of ETc. There was no significant difference between observed and estimated values. However, there were maximum differences of $15.4 \%$ in pod dry mass (Figure $3 \mathrm{~A}$ ), $6.2 \%$ in total biomass (Figure 3B) and $9.7 \%$ in grain yield (Figure 3C) between observed and estimated values under irrigation depths of 125 and $150 \%$ ETc, respectively, for these variables.

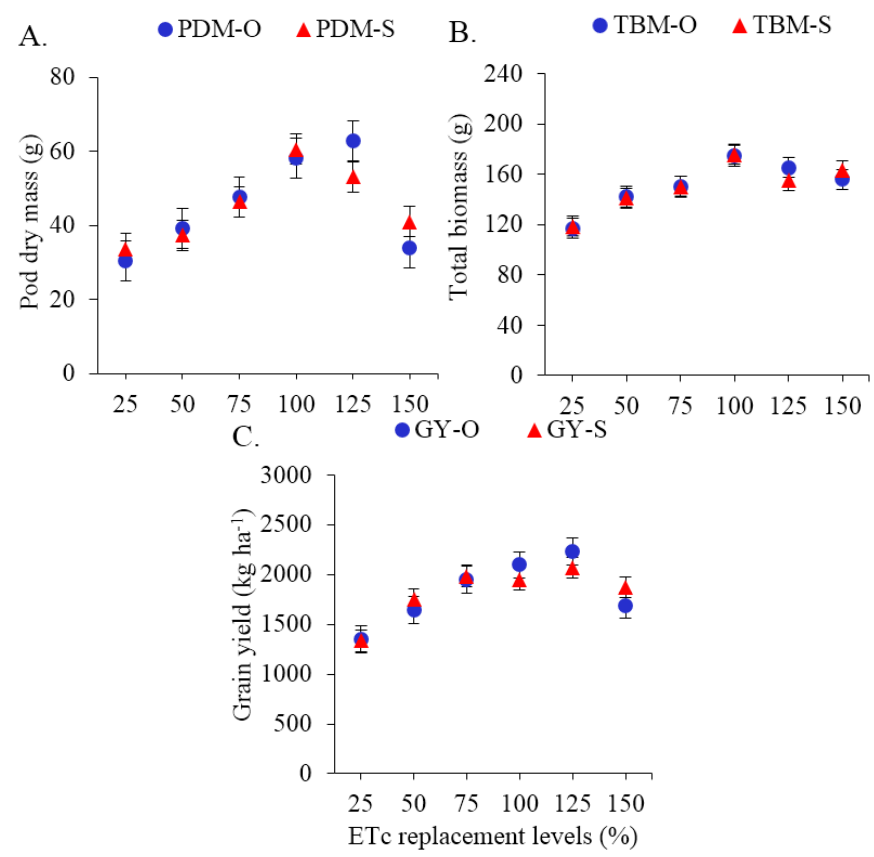

Figure 3. Comparison between observed data $(\bullet-\mathrm{O})$ and data estimated $(\boldsymbol{\Delta}-\mathrm{S})$ by the multiple regression models for: pod dry mass (PDM) (A); total biomass (TBM) (B); and grain yield (GY) (C) as a function of ETc replacement levels (\%)

Table 3. Summary of multiple regression analyses for the production components as a function of the irrigation depths based on ETc and of the growth variables

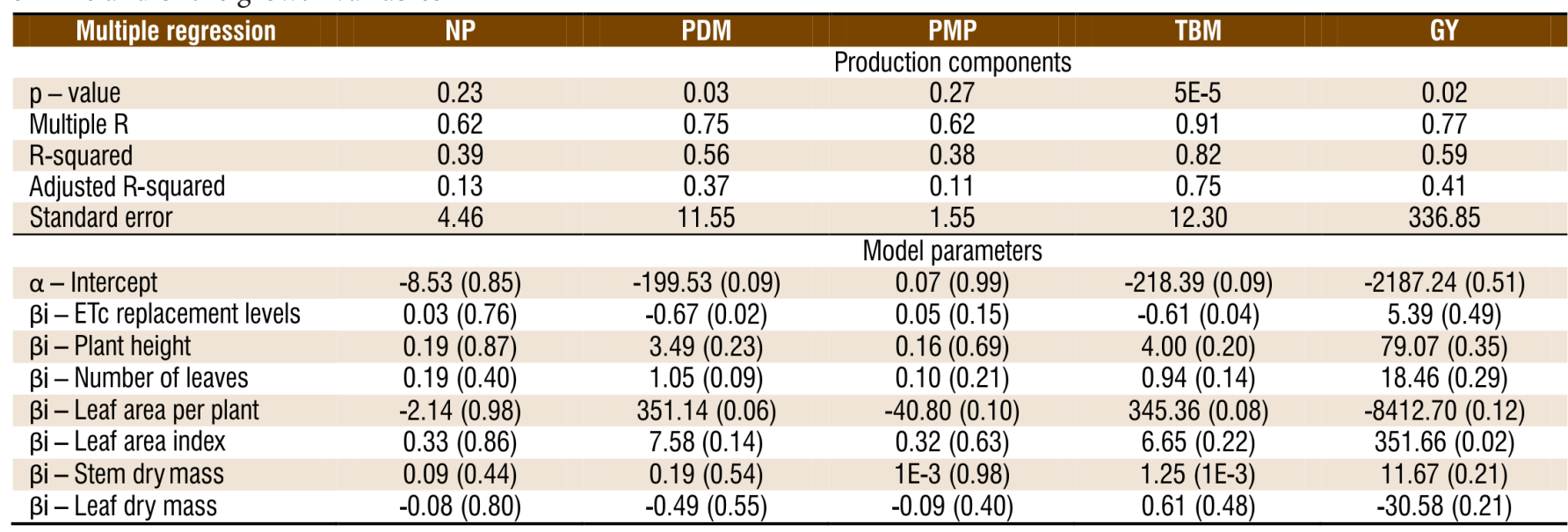

p - Probability of significance; $\mathrm{R}^{2}$ - Coefficient of determination; $\alpha$ - Linear coefficient; $\beta \mathrm{i}$ - Regression coefficient of the independent variables; NP - Number of pods per plant; PDM - Pod dry mass; PMP - Pod mass per plant; TBM - Total biomass; GY - Grain yield; Values between parenthesis indicate the probability of significance of the model parameters 
Previous knowledge on the dry mass accumulation and grain yield of crops is a strategy for decision-making in the management of production factors. Hence, the use of simulation models allows analyzing scenarios, considering different combinations of factors influencing crop yield (Gomes et al., 2014). For Rosa et al. (2010), these models allow identifying, along the crop cycle, factors that negatively act on yield, guiding the decision-making process. Barbosa et al. (2019) confirm the importance of these multiple regression models, especially for estimating variables that demand high cost and time for evaluation.

Based on all the information above, the multiple regression models adjusted in this study can be used as an aid tool for decision-making regarding the management of replacement of water evapotranspired by the common bean crop under the studied conditions, notably for the possibility of pre-estimating pod dry mass, total biomass accumulation and grain yield.

\section{Conclusions}

1. Higher growth and production of common bean 'Rosinha' variety, are obtained with the irrigation depth of $100 \%$ of the evapotranspired water.

2. Growth variables measured at 35 days after sowing can be used to adjust multiple regression models to estimate pod dry mass, total biomass accumulation and grain yield of common bean.

\section{Literature Cited}

Abd El-Wahed, M. H.; Baker, G. A.; Ali, M. M.; Abd El-Fattah, F. A. Effect of drip deficit irrigation and soil mulching on growth of common bean plant, water use efficiency and soil salinity. Scientia Horticulturae, v.225, p.235-242, 2017. https://doi.org/10.1016/j. scienta.2017.07.007

Allen, R. G.; Pereira, L. S.; Raes, D.; Smith, M. Crop evapotranspiration: Guidelines for computing crop water requirements. Rome: Food Agriculture Organization, 1998. 300p.

Araújo, A. P.; Teixeira, M. G. Variabilidade dos índices de colheita de nutrientes em genótipos de feijoeiro e sua relação com a produção de grãos. Revista Brasileira de Ciências do Solo, v.36, p.137-146, 2012. https://doi.org/10.1590/S0100-06832012000100015

Arf, O.; Rodrigues, R. A. F.; Sá, M. E. de; Buzetti, S.; Nascimento, V. do. Manejo do solo, água e nitrogênio no cultivo de feijão. Pesquisa Agropecuária Brasileira, v.39, p.131-138, 2004. https:// doi.org/10.1590/S0100-204X2004000200005

Ávila, M. R.; Barizão, D. A. O.; Gomes, E. P.; Fedri, G.; Albrecht, L. P. Cultivo de feijoeiro no outono/inverno associado à aplicação de bioestimulante e adubo foliar na presença e ausência de irrigação. Scientia Agraria, v.11, p.221-230, 2010. https://doi.org/10.5380/ rsa.v11i3.17230

Barbosa, M. de A.; Ferraz, R. L. de S.; Coutinho, E. L. M.; Coutinho Neto, A. M.; Silva, M. S. da; Fernandes, C.; Rigobelo, E. C. Multivariate analysis and modeling of soil quality indicators in long-term management systems. Science of the Total Environment, v.657, p.457-465, 2019. https://doi.org/10.1016/j.scitotenv.2018.11.441

Brasil. Ministério da Agricultura e Reforma Agrária. Regras para análise de sementes. Brasília: MAPA, 1992. 365p.
Brito, J. E. D. de; Almeida, A. C. dos S.; Lyra, G. B.; Ferreira Junior, R. A.; Teodoro, I.; Souza, J. L. de. Produtividade e eficiência de uso da água em cultivo de feijão sob diferentes coberturas do solo submetido à restrição hídrica. Revista Brasileira de Agricultura Irrigada, v.10, p.565-575, 2016. https://doi.org/10.7127/rbai. v10n200405

Cargnelutti Filho, A.; Storck, L.; Lúcio, A. D. C. Identificação de variáveis causadoras de erro experimental na variável rendimento de grãos de milho. Ciência Rural, v.34, p.707-713, 2004. https:// doi.org/10.1590/S0103-84782004000300009

CONAB - Companhia Nacional de Abastecimento. Acompanhamento de safra brasileira: Grãos - Safra 2015/16. Décimo primeiro levantamento. Available on: <http://www.conab.gov.br $>$. Accessed on: Aug. 2016.

CONAB - Companhia Nacional de Abastecimento. Acompanhamento de safra brasileira: Grãos - Safra 2016/17. Sétimo levantamento. Available on: <http://www.conab.gov.br/ >. Accessed on: May 2017.

Cunha, P. C. R. da; Silveira, P. M. da; Nascimento, J. L. do; Alves Júnior, J. Manejo da irrigação no feijoeiro cultivado em plantio direto. Revista Brasileira de Engenharia Agrícola e Ambiental, v.17, p.735742, 2013. https://doi.org/10.1590/S1415-43662013000700007

Dutra, A. F.; Melo, A. S. de; Filgueiras, L. M. B.; Silva, A. R. F. da; Oliveira, I. M. de; Brito, M. E. B. de. Parâmetros fisiológicos e componentes de produção de feijão-caupi cultivado sob deficiência hídrica. Revista Brasileira de Ciências Agrárias, v.10, p.189-197, 2015. https://doi.org/10.5039/agraria.v10i2a3912

Fernandez, F. do C.; Gepts, P.; Lopes, M. Etapas de desarollo de la planta de frijol comum. Cali: Centro Nacional de Agricultura Tropical, 1982. 26p.

Ferraz, R. L. de S.; Melo, A. S. de; Suassuna, J. F.; Brito, M. E. B. de; Fernandes, P. D. Nunes Júnior, E. da S. Trocas gasosas e eficiência fotossintética em ecótipos de feijoeiro cultivados no semiárido. Pesquisa Agropecuária Tropical, v.42, p.181-188, 2012a. https:// doi.org/10.1590/S1983-40632012000200010

Ferraz, R. L. de S.; Melo, A. S. de; Suassuna, J. F.; Ferreira, R. de S. Fernandes, P. D. Desenvolvimento e produção de ecótipos de feijoeiro cultivados na época das águas, sob irrigação suplementar. Bioscience Journal, v.28, p.920-928, 2012 b.

Ferreira Junior, R. A.; Souza, J. L. de; Escobedo, J. F.; Teodoro, I.; Lyra, G. B.; Araújo Neto, R. A. de. Cana-de-açúcar com irrigação por gotejamento em dois espaçamentos entrelinhas de plantio. Revista Brasileira de Engenharia Agrícola e Ambiental, v.18, p.798-804, 2014. https://doi.org/10.1590/1807-1929/agriambi. v18n08p798-804

Floss, E. L. Fisiologia das plantas cultivadas. Passo Fundo: Editora da UPF, 2004. 536p.

Gomes, A. C. dos S.; Robaina, A. D.; Peiter, M. X.; Soares, F. C.; Parizi, A. R. C. Modelo para estimativa da produtividade para a cultura da soja. Ciência Rural, v.44, p.43-49, 2014. https://doi.org/10.1590/ S0103-84782013005000145

Goulart, M. M. P.; Walker, R.; Gonçalves, A. H.; Costa, K. A. de P.; Braz, A. J. B. P. Crescimento vegetativo de cultivares de feijoeiro submetido a dois níveis de luminosidades. Global Science and Technology, v.3, p.31-39, 2010.

Hair, F. J.; Black, W. C.; Babin, B. J.; Anderson, R. E.; Tatham, R. L. Análise multivariada de dados. Porto Alegre: Bookman, 2009. $688 \mathrm{p}$. 
Hotelling, H. Multivariate quality control. In: Eisenhart, C.; Hastay, M. W.; Wallis, W. A. Techniques of statistical analysis. New York: John Wiley \& Sons, 1947. Chap.3, p.113-184.

Liang, X.; Liakos, V.; Wendroth, O.; Vellidis, G. Scheduling irrigation using an approach based on the van Genuchten model. Agricultural Water Management, v.176, p.170-179, 2016. https:// doi.org/10.1016/j.agwat.2016.05.030

Lima, J. S.; Assunção, I. P.; Teodoro, I.; Lima, G. S. A.; Michereff, S. J. Influência do sistema de irrigação na incidência e nas perdas ocasionadas pelo mosaico dourado do feijoeiro. Tropical Plant Pathology, v.36, p.50-53, 2011. https://doi.org/10.1590/S198256762011000100008

Magalhães, I. D.; Lyra, G. B.; Souza, J. L.; Teodoro, I.; Cavalcante, C. A.; Ferreira Junior, R. A.; Souza, R. C. Physiology and grain yield of common beans under evapotranspirated water reposition levels. Irrigation \& Drainage Systems Engineering, v.6, p.2-8, 2017.

Michels, A. F.; Souza, C. A.; Coelho, C. M. M.; Zilio, M. Qualidade fisiológica de sementes de feijão crioulo produzidas no oeste e planalto catarinense. Revista Ciência Agronômica, v.45, p.620 632, 2014. https://doi.org/10.1590/S1806-66902014000300025

Padilla-Chacón, D.; Martínez-Barajas, E.; García-Esteva, A.; LealDelgado, R.; Kohashi-Shibata, J.; Peña-Valdivia, C. B. Biomass remobilization in two common bean (Phaseolus vulgaris L.) cultivars under water restriction. South African Journal of Botany, v.112, p.79-88, 2017. https://doi.org/10.1016/j.sajb.2017.05.015
Ramos Junior, E. U.; Lemos, L. B.; Silva, T. R. B. da. Componentes da produção, produtividade de grãos e características tecnológicas de cultivares de feijão. Bragantia, v.64, p.75-82, 2005. https://doi. org/10.1590/S0006-87052005000100008

Rocha, A. E. Q. da; Lyra, G. B.; Souza, J. L. de; Lyra, G. B.; Medeiros, R. P.; Teodoro, I. Conteúdo de água no solo por reflectometria no domínio do tempo e balanço de água no solo em cultivo de milho. Irriga, v.19, p.267-278, 2014. https://doi.org/10.15809/ irriga.2014v19n2p267

Rosa, V. G. C. da; Moreira, M. A.; Rudorff, B. F. T.; Adami, M.; Estimativa da produtividade de café com base em um modelo agrometeorológico-espectral. Pesquisa Agropecuária Brasileira, v.45, p.1478-1488, 2010. https://doi.org/10.1590/S0100204X2010001200020

Souza, J. L. de; Nicácio, R. M.; Moura, M. A. L. Global solar radiation measurements in Maceió, Brasil. Renewable Energy, v.30, p.12031220, 2005. https://doi.org/10.1016/j.renene.2004.09.013

Souza, J. V. R. S.; Saad, J. C. C.; Roman, R. M. S.; Sinobas, L. R. No-till and direct seeding agriculture in irrigated bean: Effect of incorporating crop residues on soil water availability and retention, and yield. Agricultural Water Management, v.170, p.158-166, 2016. https://doi.org/10.1016/j.agwat.2016.01.002

Torres, J. L. R.; Santana, M. J.; Pizolato Neto, A; Pereira, M. G.; Vieira, D. M. da S. Produtividade de feijão sobre lâminas de irrigação e coberturas de solo. Bioscience Journal, v.29, p.833-841, 2013. 